\title{
Effects of Climate Change in North America: An Overview
}

\author{
Rachel J.C. Chen, Ph,D., CHE \\ Director \\ Center for Sustainable Business and Tourism \\ The University of Tennessee, USA \\ Tel: 1-(865)-974-0505 E-mail: rchen@utk.edu
}

Received: March 1, 2011

Accepted: March 14, 2011

doi:10.5539/jsd.v4n3p32

\begin{abstract}
As forecast by many researchers, climate change can be expected to impact regions through direct effects (e.g., temperature shifts, changes in sea level, extreme weather events, and precipitation changes) and indirect effects (e.g., migrations of species and changes in ecosystems). Previous studies have reported how various regions will face challenges as to adaptations and vulnerabilities brought on by climate change differently according to their wealth. Interrelated impacts have been forecast to occur in North America stemming from variations due to climate change, including economic, ecological, environmental, and social impacts. This study overviews the effects (direct and indirect) of climate change on various sectors in North America. It concludes, along with the suggestions of the Intergovernmental Panel on Climate Change's (IPCC) Fourth Assessment Report (AR4), that future studies should focus on regional studies of climate change, impacts of extreme weather events, and in-depth integrated models for mitigation, adaptation, and impact based on future simulations of climate change.
\end{abstract}

Keywords: Temperature shifts, Sea level, Extreme weather events, Migrations of species

\section{Introduction}

As forecast by many researchers, climate change can be expected to impact regions through direct effects (e.g., temperature shifts, changes in sea level, extreme weather events, and precipitation changes) and indirect effects (e.g., migrations of species and changes in ecosystems). Previous studies (Parson, 2003; Smith et al., 2005; Thomson, 2005a, 2005b, 2005c; Füssel, 2009) have reported how various regions will face challenges as to adaptations and vulnerabilities brought on by climate change differently according to their wealth.

The increase in the frequency and intensity of extreme weather events over the past decades has been notable and well documented (Meehl \& Tebaldi, 2004; Christensen et al., 2007; Meehl et al., 2007; Emanuel et al., 2008). The productivity of agriculture, forestry and tourism industries is sensitive to the climate. Public and private sectors related to waterfront properties (utilities, infrastructure, transportation, and resorts, etc.) are vulnerable during and after extreme weather events (Statistics Canada, 2006; Bureau of Transportation Statistics, 2006). Aging populations are also sensitive to climate change. Weather-related diseases cause an increase in urgent hospital admissions resulting in increased health care costs (Burleton, 2002). Extreme weather events have quite severe impacts on transportation systems (Lonergan et al., 1993), energy supplies, and other industries in North America. For example, major hurricanes in 2004 and 2005 in the US impacted oil and natural gas platforms and pipelines and caused high restoration costs in the billions of dollars for public utilities and transportation networks on the regional and national level (EEI, 2005).

Communities that rely on natural and water resources are sensitive to extreme weather events. Heavy rainfall, hurricanes, and ice storms affect quality of life and constrain economic activity. Community infrastructures are exposed to damage from tree insects, coastal erosion, rising sea levels, flooding, and storm waters. Fishing, hunting, whaling, travel, and various recreational activities have been affected by weather threats that have limited economic activities in these natural resource-dependent communities (NAST, 2001; CCME, 2003).

More frequent and intense extreme weather events have placed stresses on coastal communities, impacted ecosystems, increased coastal damage, and affected greater numbers of people during and after extreme weather events. For example, Alaskan villages, the Great Lakes area, the Gulf of St. Lawrence, and many other coastal communities that are within exposure range of tropical storms or winter storms have demonstrated their vulnerability and limited adaptive capacities (Clark et al., 1998; Parson et al., 2001; West et al., 2001; Scavia et al., 2002; Burkett et al., 2005). 
Because of changes to ecosystems caused by climate change, commercial and recreational fisheries and plants must adjust to new spatial distribution of species. The uncertain productivity of forests will determine levels of carbon stock. The increase in length and scale of forest fires, loss of coastal and inland wetlands, and changes in high alpine areas and cold waters are all due to changes in forest and water ecosystems. For populations facing possible water availability issues in the western snowmelt-dominated region, some strategic adaptations may involve shifting seasonal runoff. Experts and climate-change-related centers have urged enhanced adaptation strategies, including more solid infrastructure plans (e.g., improving building codes and enhancing disaster preparedness), in order to prevent disasters that may be caused by extreme weather events associated with climate change.

More cities are forecast to experience extreme heat waves, increasing sea levels, increased numbers of dangerous storm surges, water shortages, droughts, and increased flooding. Stressors (severe heat waves, extreme weather events, and air pollution) generated by climate change may cause social disruption and increased human losses and injuries, as well as vector-borne and tick-borne diseases. This study overviews the effects (direct and indirect) of climate change on various sectors in North America.

\section{Direct Effects}

\subsection{Changes in Temperature}

Previous studies have thoroughly documented the increase in annual mean air temperature in North America over the past forty years (1969-2009). For example, night-time temperatures have increased more than day-time temperatures, while spring and winter have demonstrated more warming than other seasons (Karl et al., 1996; Brown \& Hunt, 2007; Füssel, 2009; Pederson, et al., 2010). Geographically, Alaska and northwestern Canada have shown the most significant warming, followed by the continental interior, the southeastern US, and eastern Canada. Because of the combination of greenhouse gas effects and sulphate aerosols (Karoly et al., 2003; Stott, 2003; Zwiers \& Zhang, 2003), spring warming has extended the growing season an average of 2 days per decade (Bonsal et al., 2001; Easterling, 2002; Bonsal \& Prowse, 2003; Feng \& Hu, 2004). Temperature-specific terms relevant to the selected articles as to temperature changes between seasons and geographical locations due to climate change, study methods, and suggestions for future studies are presented in Table 1.

[insert Table 1 about here]

\subsection{Rising Sea Levels}

Aggressive coastal investment plans, increasing coastal populations (both local and non-local), extended urbanization, and rising property values are adding stress to the ecosystems of coastal regions and revealing vulnerabilities to rising sea levels and severe storms resulting from climate change (Kleinosky et al., 2007; Füssel, 2009). Sea levels are forecast to rise at an accelerating pace over time, especially in eastern North America and western Alaska (Zhang et al., 2000; Church et al., 2004; Meehl et al., 2007; Cooper et at., 2008; $\mathrm{Wu}$, et al., 2009).

Many previous studies have documented the correlations between rising sea levels, coastal and inland erosion, and more frequent and intense storms in the US (Meehl et al., 2007; Travis, 2010). Economic damage, unstable coastlines, and affected populations during and after extreme weather events (hurricanes, storms, wind, waves, ice encroachment) have been forecast to increase continuously in the coming decade (Zhang et al., 2000; Scavia et al., 2002; Emanuel, 2005). Increasing sea levels along with strong windstorms have already been reported to cause increasing damage on the Gulf and Atlantic coasts. Additionally, Wu et al. (2009) estimated that nearly 510,000 people and $1,000 \mathrm{~km}$ of roads will be impacted by rising sea levels due to inundation in the coastal portion of the Mid and Upper Atlantic Regions of the US by 2100. Rising sea levels relevant to the assessment of impacts of climate change on various sectors along with the studied regions, research methods, brief findings, and suggestions for future study are shown in Table 2.

[insert Table 2 about here]

\subsection{Extreme Weather Events}

Storms. As mentioned above, the impacts of rising sea levels on the coastal regions of North America have been heavily documented (Travis, 2010). Many coastal communities and waterfront properties have been facing the dangers associated with storm surges and disruptive flooding over the years (Pielke et al., 2008; Kossin\& Camargo 2009). For example, hurricanes Ivan in 2004 and Katrina, Rita and Wilma in 2005 had an enormous impact on infrastructure (Select Bipartisan Committee, 2006). In 2005 Hurricane Katrina flooded New Orleans, due to inadequate public evacuation plans and strategically sound emergency services, the impact of Hurricane Katrina in particular on the total affected population was disastrous (Balling \& Cerveny, 2003). In 2006 storm 
surges battered Delta, British Columbia, and winter storms caused severe flooding and coastal erosion in San Francisco and along the Pacific coast (Bromirski et al., 2003; Edmiston et al., 2008). Settlements with high population density along the coasts, aging infrastructures, outdated building codes, urbanization, and ineffective and untimely warning systems have amplified the damage caused by these extreme weather events (Easterling et al., 2000; Balling \& Cerveny, 2003; Changnon, 2003, 2005). Extreme-weather-specific terms relevant to the impacts of extreme weather events and natural disasters on various social-economic sectors are presented in Table 3. It also summarizes studied regions, research methods, brief findings, and suggestions for future study.

[insert Table 3 about here]

Economic damage. Over the last 10 years (2000-2009), storms, floods, hurricanes, and wildfires, have caused most of the major economic damage (USAID, 2009). Approximately $95 \%$ of the affected populations were impacted by floods, storms, droughts, and wildfires, while floods, extreme temperatures, and storms caused $93 \%$ of human loss in North America in the past decade (BC Stats, 2003; USAID, 2009; Chen, 2011). Looking ahead, coastal areas and ski resorts have been forecast to receive significant negative impacts brought about by climate change. For example, because of increasing sea levels along the beaches in the state of Florida, billions of dollars will be spent for sand replenishment (Jones \& Scott, 2006). Losses of ski zones at lower elevations are forecast to result in shortened snow seasons (7-10 weeks), decreased visitation, and diminished tourism receipts. Western North America is forecast to have its non-artificial-snow ski season shortened by 3 to 6 weeks (Hayhoe et al., 2004; Scott \& Jones, 2005).

From 1998 to 2008, major storms cost an average of USD \$50 million/storm, with the highest single storm (Katrina in 2005) having an impact of USD \$2 billion (Business Week, 2005). Warmer weather triggered regional power outages resulting in millions in insured losses as well as total losses due to business interruptions in the billions (LaCommare \& Eto, 2004; USAID, 2009).

Diseases. Extreme weather events (e.g., heat waves, air pollution, heavy precipitation, and droughts) endanger human health, having been documented to be correlated with increased urgent hospital admissions and mortality rates (Kolivras \& Comrie, 2003; Patz et al., 2005; Thomas et al., 2006; Gosling, et al., 2009). For example, respiratory and cardiovascular illnesses are sensitive to air pollution and heat waves. Heavy precipitation has caused water-borne disease outbreaks, while heavy runoff can contaminate watersheds and increase bacterial counts. Statistics show that West Nile virus, vector-borne illness, and Lyme disease have been associated with warming temperatures in North America (McCabe \& Bunnell, 2004). The impacts of extreme weather events on diseases are presented in Table 4.

[insert Table 4 about here]

\subsection{Variations in Stream Flow}

Many factors (such as increased population; demand for water resources due to industrial, agricultural, and municipal needs; and changes in water quality and ecosystems) have affected the allocation of water resources and may have resulted in extended droughts in North America (Dupigny-Giroux, 2001; Wheaton et al., 2005; Kunkel \& Pierce, 2010). For example, in the central Rocky Mountain region, stream flows have decreased nearly two percent per decade since 1910 (Rood et al., 2005) while there has been a $25 \%$ increase in stream flows in the eastern US over the past three decades (Groisman et al., 2005). According to Knowles et al. (2006), 74\% of weather stations have documented an increase in precipitation (as rain not snow) in the western mountains of the US. On the other hand, because of regional warming, in the western mountains of North America, there has been a decrease in water from snow ranging from between 15 to 30\% since the 60s (Groisman et al., 2005; Mote et al., 2005; Lemke et al., 2007), while Canada has experienced a decrease in both precipitation and snowfall in the west and Prairies (Vincent \& Mekis, 2006). However, trends in the moisture index show various divisions in levels of wetness due to variations in precipitation and evapotranspiration. An increase in precipitation and a decrease in evapotranspiration (a reflection of higher air temperatures) would lead to a wetter outcome, for example, in the southern region of the US (Grundstein, 2009).

Underground and surface water resources are needed for agriculture and ecological systems. Climate change impacts the capacities of freshwater resources across regions, and exposes their vulnerability (Loukas et al., 2002; Branfireun \& Macrae, 2009). Examples have included increased winter snow-melts and earlier spring flows and decreased flows in summer (Christensen et al., 2007; Merritt et al., 2006; Miller et al., 2003). Evaporation and precipitation rates are related to the warming weather. Warming temperatures impact the timing of snow-melting and water flows across seasons. Expanding dry seasons and water levels that vary from region to region impact the availability of watersheds and influence water quality (Lemmen \& Warren, 2004). 
Decreased or ceased water flows from springs, water shortages, and decreased ground water recharge are forecast for the southwestern US due to climate change (Loáiciga et al., 2000), while river stages are forecast to change in south-central British Columbia (Allen et al., 2004). Decreased agricultural productivity, shifted water allocations, and water reduction have caused millions of dollars in losses (Chen et al., 2001). Extended warming in the summer has contributed to higher temperatures (an increase of from 2 to $7^{\circ} \mathrm{C}$ ) of streams, rivers, lakes, and reservoirs (Gooseff et al., 2005), causing lower oxygen levels and decreased flows (Fang \& Stefan, 1999), and affecting fish allocations and growth rates (Morrison et al., 2002). Expanded erosion seasons have impacted the quality of soil and water resulting in changing agricultural yields and challenges to ecosystems (Füssel, 2009). Stream-flow-specific terms relevant to the assessment of inter-relationships between precipitation, snow water, and water resource allocations are presented in Table 5. The selected articles, study methods, findings, and suggestions for further study are also provided.

[insert Table 5 about here]

\section{Indirect Effects}

\subsection{Ecosystems}

Due to regional differences, trends of increasing temperatures and changing precipitation rates have been documented with no uniform ecosystem impacts across the continent of North America (Millett et al., 2009). Climate change has caused ecosystem disturbances resulting in losses in both native and exotic species (Sala et al., 2000). For example, warming temperatures and fluctuating water supplies have impacted sustainable productivity and rates of mortality among recreational inland fisheries and commercial fisheries, for salmonid species and walleye in North America (Babaluk et al., 2000; Chapin et al., 2000; Schindler, 2001; O'Neal, 2002; Chu et al., 2003; Gallagher \& Wood, 2003; Baldocchi \& Valentini, 2004; Lester et al., 2004; Chu et al., 2005; Reed \& Czech, 2005; Rose, 2005). The warming climate has extended growing seasons and increased evaporation rates (Gerber et al., 2004; Woodward \& Lomas, 2004; Pederson et al., 2010). Biological invasions (Zavaleta \& Hulvey, 2004), wildfires (Smit et al., 2000), and climate change have resulted in changes in plant species, shifts in tree species (Morgan et al., 2001), changes in the production of amphibian eggs (Beebee, 1995), and shifts in breeding migrations. According to Thomas et al. (2004), one to twenty nine percent of animal and plant species globally will become extinct by the year 2050 .

Biogeographical distribution, primary production, and phenology are the three main linking factors related to climate and terrestrial ecosystems. Competition, herbivores, disease, wildfire, hurricanes, droughts, and human activities have direct and indirect impacts on organisms. These effects may cause plant species to flower earlier, perhaps resulting in such things as earlier first flights of butterflies (Forister \& Shapiro, 2003), or changes in the color of fall leaves (Beaubien \& Freeland, 2000; Schwartz \& Reiter, 2000; Cayan et al., 2001; Hicke \& Lobell, 2004; Wolfe et al., 2005; Boisvenue \& Running, 2006).

Along the east coast of the US, 28 migrating bird species have shown earlier nesting behavior, while tree swallows and Mexican jays have been observed in earlier egg laying due to warmer springs (Brown et al., 1999; Butler, 2003). Species that have demonstrated earlier breeding include frogs (Gibbs \& Breisch, 2001) and red squirrels in Canada (Reale et al., 2003), while some other species have experienced higher mortality rates (for example, fungal parasites) and changes of habitation northward (for example, red wolves) (Hersteinsson \& Macdonald, 1992; Kiesecker et al., 2001; Pounds, 2001).

Forest fires. Commercial forestry is sensitive to wildfires, insects, diseases, and climate change (Flannigan et al., 2004; Gan, 2004; Woods et al., 2005). The increase in summer temperatures has been forecast to increase the risk of forest fires. The range of emissions scenarios (from low to high) has also been forecast to impact harvest volumes and revenues (Perez-Garcia et al., 2002; Sohngen \& Sedjo, 2005). Various factors triggering wildfires include droughts, snowmelting, the warming climate, and dead trees from insect outbreaks and diseases (Volney \& Fleming, 2000; Williams \& Liebhold, 2002; Logan et al., 2003; Kunkel \& Pierce, 2010). In North America, areas burned by wildfires increased from 2 to 6 times and the length of fire durations increased from 7 days to 40 days compared to previous decades, resulting in increased property and human losses (Schoennagel et al., 2004; Westerling et al., 2006; Running, 2006). Additionally, three correlated factors (drought, warming weather, and water shortages) have negatively impacted growth rates and yield performances for forests in North America (Barber et al., 2000; Caspersen et al., 2000; McKenzie et al., 2001; Joos et al., 2002; Peterson et al., 2002; Boisvenue \& Running, 2006).

Agricultural yields. Crop yields are sensitive to weather, water resources, pest invasions, and sustainable land-use practices (Lobell \& Asner, 2003). Studies have shown that various crops (corn, rice, sorghum, soybean, wheat, common forages, cotton, and some fruits) (Adams et al., 2003; Rosenberg et al., 2003; Tsvetsinskaya et 
al., 2003; Antle et al., 2004; Thomson et al., 2005c), and irrigated grains (Thomson et al., 2005c) may benefit from the warming weather. The southeastern US and the corn-belt are more sensitive to weather changes than the Great Plains (Carbone et al., 2003; Mearns et al., 2003). Nevertheless, controversy as to how CO2 has impacted crop growth rates exists in the literature (Long et al., 2005; Durandeau, et al., 2010). Other weather-related factors (frost, an earlier spring, and disastrous winter thaws) and market competition have also impacted economic gains from crop yields (Bélanger et al., 2002; Mearns et al., 2003).

The vulnerability of the agricultural sector has increased because of its exposure to various severe weather events along with changes in market values (Tarnoczi \& Berkes, 2010). Improved water conservation and crop diversity, changes to public policies, and strategic soil adaptations have been utilized to enhance the capacity of the agricultural sector to cope with challenges stemming from climate change (Smit \& Skinner, 2002; Easterling et al., 2003; Senate of Canada, 2003; Wall \& Smit, 2005; Wheaton et al., 2005). Over the past 20 years, heavy rainfall and climate fluctuations have had mildly positive impacts on the yields of corn and soybeans, and have been positive factors for the growth of walnuts and oranges, but have been negative for cotton and avocados (Lobell et al., 2007).

\section{Climate Model Simulations}

Changes in atmospheric circulation affect climate extremes in North America. To better understand potential changes in weather and climate extremes, more extensive access to high temporal resolution data (daily, hourly) from climate model simulations is needed. According to the most recent climate combined simulations, the year-round temperature increase is forecast to range between 1 to $3^{\circ} \mathrm{C}$ over the years 2010 to 2039 (Christensen et al., 2007). The greatest warming is forecast to occur in winter at high latitudes and in summer in the southwestern US, and the southwestern US is forecast to experience decreased mean precipitation annually while the rest of the US will experience an increase in annual mean precipitation. In the same period, annual mean precipitation is forecast to increase from between $20 \%$ to $30 \%$ in the winter in Canada. As measured by the Power Dissipation Index, there has been a strong statistical connection between tropical Atlantic sea surface temperatures and Atlantic hurricane activity over the past 50 years. However, the phenomenon is still under-documented in relation to accurate predictions of sea surface temperature in tropical cyclone formation regions (Meehl et al., 2007; Füssel, 2009).

Usages of energy. Climate change has impacts on the usage of energy, water power, and transportation systems. Several studies have concluded that summer electricity consumption will increase while heating degree days will decrease in the winter peak season (Morrison \& Mendelsohn, 1999; Mendelsohn, 2001; Sailor \& Pavlova, 2003; Scott et al., 2005; Hadley et al., 2006). According to the United States Global Change Research Program (2009), rising temperatures will likely increase energy demand for cooling and reduce energy demand for heating. In the United States, since cooling in buildings is provided by electricity while heating is provided by natural gas and fuel, there will be an increase in the use of electricity and a decrease in the use of gas/fuel. Because half of the nation's electricity is generated from coal, the increase in demand for electricity will likely result in increased levels of carbon dioxide emissions.

\section{Conclusions and Suggestions}

Interrelated impacts have been forecast to occur in North America stemming from variations due to climate change, including economic, ecological, environmental, and social impacts, as well as social and ecological changes. All the mentioned impacts will not exist in isolation at the regional, national, or international levels. For example, temperature changes will impact the quality of life of species, and may cause more frequent weather extremes, increased erosion, changes in biodiversity, increased numbers of invasive insects and diseases, changed moisture balances, and increased wildfires. Transformations of populations and urbanization are forecast to impact watershed resources and various kinds of power usage as well as emissions and air pollution. Types of recreation and tourism activities will be impacted because of the damage inflicted by severe natural disasters (Chen, 2011).

Reducing greenhouse gas emissions and adapting to the impacts of climate change have been the two major responses to the Kyoto Protocols. The IPCC's Second Assessment Report (SAR) raised awareness of the use and production of energy and $\mathrm{CO} 2$, and enhanced understanding of carbon sinks, but paid little attention to adaptation and greenhouse gas emissions. The Third Assessment Report (TAR) pointed out the importance of both adaptation and mitigation as actions for direct and indirect prevention. However, it failed to provide integrated strategies for assessment and strategic levels. The IPCC's Fourth Assessment Report (AR4) included many elements that emphasized the importance of conducting inter-relationship assessments for various sectors 
(Meehl et al., 2007). It concluded that research literature and findings lack guidance for integration as to adaptation and mitigation.

Suggestions regarding adaptive strategies from previous studies were based on past posted trends and experiences. Prevention and adaptation for future predictions are needed as a practical matter. The accountability of scientific research outcomes coupled with optimal practices regarding climate change will increase the efficiency of adaptive capacity (Meehl et al., 2007). This study concludes, along with the suggestions of the AR4, that future studies should focus on regional studies of climate change, impacts of extreme weather events, and in-depth integrated models for mitigation, adaptation, and impact based on future simulations of climate change. For example, future studies may consider exploring integrated relationships among mitigation, impacts, and adaptations as to private action, public arrangements, and inter/national policies at all levels. Providing more feasible implementation of impact preventions and risk controls will also ensure effective global governance in climate change policy. In order to accomplish the mission of the climate change policy and enhance the global social responsibility, an integrated system that can facilitate implementation of adaptation, mitigation, and sustainable development is needed in a timely manner.

\section{Acknowledgements}

The author would like to thank Dr. Joshua Fu, Dr. Don Worster and Dr. Robert O. Mendelsohn for contributing their valuable insights to this study. The author also would like to thank the Office of Research at the University of Tennessee for the SARIF fund.

\section{References}

Adams, R.M., McCarl, B.A., \& Mearns, L.O. (2003). The effects of spatial scale of climate scenarios on economic assessments: An example from U.S. agriculture. Climatic Change, 60, 131-148.

Allen, D.M., Mackie, D.C., \& Wei, M. (2004). Groundwater and climate change: a sensitivity analysis for the Grand Forks aquifer, southern British Columbia, Canada. Hydrogeol. J., 12, 270-290.

Antle, J.M., Capalbo, S.M., Elliott, E.T., \& Paustian, K.H. (2004). Adaptation, spatial heterogeneity, and the vulnerability of agricultural systems to climate change and $\mathrm{CO} 2$ fertilization: An integrated assessment approach. Climatic Change, 64, 289-315.

Babaluk, J.A., Reist, J.D., Johnson, J.D., \& Johnson, L. (2000). First records of sockeye (Oncorhynchus nerka), and pink salmon (O. gorbuscha), from Banks Island and other records of Pacific salmon in Northwest territories. Canada Arctic, 53, 161-164.

Baldocchi, D., \& Valentini, R. (2004). Geographic and temporal variation of carbon exchange by ecosystems and their sensitivity to environmental perturbations. The Global Carbon Cycle: Integrating Humans, Climate, and the Natural World, C.B. Field and M.R. Raupach, Eds. Island Press, Washington, District of Columbia, 295-316.

Balling, R.C., \& Cerveny, R.S. (2003). Compilation and discussion of trends in severe storms in the United States: Popular perception versus climate reality. Natural Hazards, 29, 103-112.

Barber, V.A., Juday, G.P., \& Finney, B.P. (2000). Reduced growth of Alaskan white spruce in the twentieth century from temperature-induced drought stress. Nature, 405, 668-673.

BC Stats (2003). Tourism Sector Monitor - November 2003, British Columbia Ministry of Management Services, Victoria, 11 pp. http://www.bcstats.gov.bc.ca/pubs/tour/tsm0311.pdf. Accessed 02 September 2009.

Beaubien, E.G., \& Freeland, H.J. (2000). Spring phenology trends in Alberta, Canada: Links to ocean temperature. International Journal of Biometeorol., 44, 53-59.

Beebee, T.J.C. (1995). Amphibian breeding and climate. Nature, 374, 219-220.

Bélanger, G., Rochette, P., Castonguay,Y., Bootsma, A., Mongrain, D.,\& Ryand, A.J. (2002). Climate change and winter survival of perennial forage crops in Eastern Canada. Agron. J., 94, 1120-1130.

Boisvenue, C., \& Running, S.W. (2006). Impacts of climate change on natural forest productivity - evidence since the middle of the 20th century. Global Change Biol., 12, 862-882.

Bonsal, B.R., \& Prowse, T.D. (2003). Trends and variability in spring and autumn $\mathrm{O}^{\circ} \mathrm{C}$-isotherm dates over Canada. Climatic Change, 57, 341-358.

Bonsal, B.R., Zhang, X., Vincent, L.A., \& Hood, W.D. (2001). Characteristics of daily and extreme temperatures over Canada. Journal of Climate, 14, 1959-1976. 
Branfireun, B., \& Macrae, M.L. (2009). Advances in Canadian research coupling hydrology and water quality, 2003-2007. Can. Water Resour. J., 34, 187-194

Bromirski, P.D., Flick, R.E., \& Cayan, D.R. (2003). Storminess variability along the California coast: 1958-2000. Journal of Climate, 16, 982-993.

Browne, S.A., \& Hunt, L.M. (2007). Climate change and nature-based tourism, outdoor recreation, and forestry in Ontario : potential effects and adaptation strategies (Climate change research report ; CCRR-08). http://www.mnr.gov.on.ca/276926.pdf. Accessed 02 September 2009.

Brown, J.L., Li, S.H., \& Bhagabati, B. (1999). Long-term trend toward earlier breeding in an American bird: Aresponse to global warming? Proc. Nat. Acad. Sci., 96, 5565-5569.

Bureau of Transportation Statistics (2006). Economic Indexes: Transportation Services Index. United States Department of Transportation, Washington, District of Columbia. http://www.bts.gov/publications/white_house_economic_statistics_briefing_room/october_2005/html $/$ transportat ion_services_index.html. Accessed 02 September 2010.

Burkett, V.R., Wilcox, D.A., Stottlemyer, R., Barrow, W., Fagre, D., Baron, J., Price, J., Nielsen, J.L., Allen, C.D., Peterson, D.L., Ruggerone, G., \& Doyle, T. (2005). Nonlinear dynamics in ecosystem response to climatic change: Case studies and policy implications. Ecol. Complexity, 2, 357-394.

Burleton, D. (2002). Slowing Population, Ageing Workforce Trends More Severe in Canada than in the U.S., Executive Summary for TD Economics, Toronto, Ontario, 3 pp.

Business Week (2005). A Second Look at Katrina's Cost. Business Week. September 13, 2005. http://www.businessweek.com/bwdaily/dnflash/sep2005/nf20050913_8975_db082.htm. Accessed 12 September 2009.

Butler, C.J. (2003). The disproportionate effect of global warming on the arrival dates of short-distance migratory birds in North America. Ibis, 145, 484-495.

Carbone, G.J., Kiechle, W., Locke, L., Mearns, L.O., McDaniel, L., \& Downton, M.W. (2003). Response of soybean and sorghum to varying spatial scales of climate change scenarios in the southeastern United States. Climatic Change, 60, 73-98.

Caspersen, J.P., Pacala, S.W., Jenkins, J.C., Hurtt, G.C., Moorcroft, P.R., \& Birdsey, R.A. (2000). Contributions of land-use history to carbon accumulation in U.S. forests. Science, 290, 1148-1151.

Cayan, D.R., Kammerdiener, S.A., Dettinger, M.D., Caprio, J.M., \& Peterson, D.H. (2001). Changes in the onset of spring in the western United States. Bull. Amer. Meteor. Soc., 82, 399-415.

CCME (2003). Climate, Nature, People: Indicators of Canada's Changing Climate. Climate Change Indicators Task Group of the Canadian Council of Ministers of the Environment, Canadian Council of Ministers of the Environment Inc., Winnipeg, Canada, 51 pp.

Changnon, S.A. (2003). Shifting economic impacts from weather extremes in the United States: Aresult of societal changes, not global warming. Nat. Hazards, 29, 273-290.

Changnon, S.A. (2005). Economic impacts of climate conditions in the United States: Past, present, and future -An editorial essay. Climatic Change, 68, 1-9.

Chapin, F.S., III, Zavaleta, E.S., Eviner, V.T., Naylor, R.L., Vitousek, P.M., Reynolds, H.L., Hooper, D.U., Lavorel, S., Sala, O.E., Hobbie, S E., Mack, M.C., \& Díaz, S. (2000). Consequences of changing biodiversity. Nature, 405, 234 - 242.

Chen, R.J.C. (2011). Impacts of Natural Disasters on Regional Economics: An Overview. Tourism Analysis, $15(6)$, in press.

Chen, C., Gillig, D. \& McCarl, B. (2001). Effects of climatic change on a water dependent regional economy: a study of the Texas Edwards aquifer. Climatic Change, 49, 397-409.

Christensen, J.H., Hewitson, B., Busuioc, A., Chen, A., Gao, X., Held, I., Jones, R., Kolli, R.K., Kwon, W.T., Laprise, R., Magaña Rueda, V., Mearns, L., Menendez, C.G., Räisänen, J., Rinke, A., Sarr, A., \& Whetton, P. (2007). Regional climate projections. Climate Change 2007: The Physical Science Basis. Contribution of Working Group I to the Fourth Assessment Report of the Intergovernmental Panel on Climate Change, Solomon, S., Qin, D., Manning, M., Chen, Z., Marquis, M., Averyt, K.B., Tignor, M. \& Miller, H.L. Eds., Cambridge University Press, Cambridge and New York, 847-940. 
Chu, C., Minns, C.K., \& Mandrak, N.E. (2003). Comparative regional assessment of factors impacting freshwater fish biodiversity in Canada. Canadian Journal of Fisheries and Aquatic Sciences, 60, 624-634.

Chu, C., Mandrak, N.E., \& Minns, C.K. (2005). Potential impacts of climate change on the distributions of several common and rare freshwater fishes in Canada. Divers. Distrib., 11, 299-310.

Church, J.A., White, N.J., Coleman, R., Lambeck, K., \& Mitrovica, J.X. (2004). Estimates of the regional distribution of sea level rise over the 1950-2000 period. Journal of Climate, 17, 2609-2625.

Clark, G.E., Moser, S.C., Ratick, S.J., Dow, K., Meyer, W.B., Emani, S., Jin, W., Kasperson, J.X., Kasperson, R.E., \& Schwarz, H.E. (1998). Assessing the vulnerability of coastal communities to extreme storms: the case of Revere, MA, USA. Mitigation Adap. Strategies Global Change, 3, 59-82.

Cooper, M.J.P., Beevers, M.D., \& Oppenheimer, M. (2008). The potential impacts of sea level rise on the coastal region of New Jersey, USA. Climatic Change, 90, 475-492.

Dupigny-Giroux, L.A. (2001). Towards characterizing and planning for drought in Vermont - Part I: Aclimatological perspective. J. Amer. Water Resour. Assoc., 37, 505-525.

Durandeau, S., Gabrielle, B., Godard, C., Jayet, P.A., \& Le Bas, C. (2010). Coupling biophysical and micro-economic models to assess the effect of mitigation measures on greenhouse gas emissions from agriculture. Climatic Change, 98, 51-73.

Easterling, D.R. (2002). Recent changes in frost days and the frost-free season in the United States. Bull. Amer. Meteor. Soc., 83, 1327-1332.

Easterling, D.R., Meehl, G.A., Parmesan, C., Changnon, S.A., Karl, T.R., \& Mearns, L.O. (2000). Climate extremes: Observations, modeling, and impacts. Science, 289, 2068-2074.

Easterling, W.E., Chhetri, N., \& Niu, X.Z. (2003). Improving the realism of modeling agronomic adaptation to climate change: Simulating technological substitution. Climatic Change, 60, 149-173.

Edmiston, H.L., Fahrny, S.A., Lamb, M.S., Levi, L.K., Wanat, J.M., Avant, J.S., Wren, K., \& Selly, N.C. (2008). Tropical storm and hurricane impacts on a Gulf Coast estuary: Apalachicola Bay, Florida. Journal of Coastal Research, SI(55), 38-49.

EEI (2005). After the Disaster: Utility Restoration Cost Recovery. Edison Electric Institute (EEI), Washington, District of Columbia, 27. http://www.eei.org/industry_issues/reliability/nonav_reliability/Utility_Restoration_Cost_Recovery.pdf. Accessed 02 September 2009.

Emanuel, K. (2005). Increasing destructiveness of tropical cyclones over the past 30 years. Nature, 436, 686-688.

Emanuel, K, Sundararajan, R., \& Williams, J. (2008). Hurricanes and global warming-results from downscaling IPCC AR4 simulations. Bull Am Meteorol Soc, 89(3):347-367

Fang, X., \& Stefan, H.G. (1999). Projections of climate change effects on water temperature characteristics of small lakes in the contiguous U.S. Climatic Change, 42, 377- 412.

Feng, S., \& Hu, Q. (2004). Changes in agro-meteorological indicators in the contiguous United States: 1951-2000. Theor. Appl. Climatol., 78, 247-264.

Flannigan, M. D., Logan, K.A., Amiro, B. D., Skinner, W. R., \& Stocks, B. J. (2004). Future area burned in Canada. Climatic Change, 72, 1-16.

Foley, J.A., DeFries, R., Asner, G.P., Barford, C., Bonan, G., Carpenter, S.R., Chapin, F.S., Coe, M.T., Daily, G.C., Gibbs, H.K., Helkowski, J.H., Holloway, T., Howard, E.A., Kucharik, C.J., Monfreda, C., Patz, J.A., Prentice, I.C., Ramankutty, N., \& Snyder, P.K. (2005). Global consequences of land use. Science, 309, 570-574.

Forister, M.L., \& Shapiro, A.M. (2003). Climatic trends and advancing spring flight of butterflies in lowland California. Global Change Biol., 9, 1130-1135.

Füssel, H.M. (2009). An updated assessment of the risks from climate change

based on research published since the IPCC Fourth Assessment Report. Climatic Change, 97, 469-482

Gallagher, P., \& Wood, L. (2003). Proc. The World Summit on Salmon, June 10-13, 2003, Vancouver, British Columbia. http://www.sfu.ca/cstudies/science/summit.htm. Accessed 02 September 2009. 
Gan, J.B. (2004). Risk and damage of southern pine beetle outbreaks under global climate change. Forest Ecol. Manag., 191, 61-71.

Gerber, S., Joos, F., \& Prentice, I. C. (2004). Sensitivity of a dynamic global vegetation model vegetation model to climate and atmospheric CO2. Global Change Biol., 10, 1223-1239.

Gibbs, J.P., \& Breisch, A.R. (2001). Climate warming and calling phenology of frogs near Ithaca, New York, 1900-1999. Conserv. Biol., 15, 1175-1178.

Gooseff, M.N., Strzepek, K., \& Chapra, S.C. (2005). Modeling the potential effects of climate change on water temperature down stream of a shallow reservoir, lower Madison River, MT. Climatic Change, 68, 331-353.

Gosling, S. N., Lowe, J.A., McGregor, G.R., Pelling, M., \& Malamud, B.D. (2009). Associations between elevated atmospheric temperature and human mortality: a critical review of the literature. Climatic Change, 92, 299-341.

Groisman, P.Y., Knight, R.W., Karl, T.R., Easterling, D.R., Sun, B., \& Lawrimore, J.H. (2005). Contemporary changes of the hydrological cycle over the contiguous United States: trends derived from in situ observations. $J$. Hydrometeorol., 5, 64-85.

Grundstein, A. (2009). Evaluation of climate change over the continental United States using a moisture index. Climatic Change, 93, 103-115.

Hadley, S.W., Erickson, III, D.J., Hernandez, J.L., Broniak, C.T., \& Blasing, T.J. (2006). Responses of energy use to climate change: A climate modeling study. Geophys. Res. Lett., 33,

Hayhoe, K., Cayan, D., Field, C., Frumhoff, P., Maurer, E., Miller, N., Moser, S., Schneider, S., Cahill, K., Cleland, E., Dale, L., Drapek, R., Hanemann, R.M., Kalkstein, L., Lenihan, J., Lunch, C., Neilson, R., \& Verville, J. (2004). Emissions pathways, climate change, and impacts on California. Proc. Nat. Acad. Sci., 101, 12422-12427.

Hersteinsson, P., \& Macdonald, D.W. (1992). Inter specific competition and the geographical distribution of red and arctic foxes, Vulpes vulpes and Alopex lagopus. Oikos, 64, 505-515.

Jones, B., \& Scott, D. (2006). Climate Change, Seasonality and Visitation to Canada's National Parks. J. Parks Recreation Admin., 24, 42-62.

Joos, F., Prentice, I.C., \& House, J.I. (2002). Growth enhancement due to global atmospheric change as predicted by terrestrial ecosystem models: Consistent with US forest inventory data. Global Change Biol., 8, 299-303.

Karl, T., Knight, R., Easterling, D., \& Quayle, R. (1996). Indices of climate change for the United States. Bull. Amer. Meteor. Soc., 77, 279-292.

Karoly, D.J., Braganza, K., Stott, P.A., Arblaster, J.M., Meehl, G.A., Broccoli, A.J. \& Dixon, K.W. (2003). Detection of a human influence on North American climate. Science, 302, 1200-1203.

Kiesecker, J.M., A.R. Blaustein and L.K. Belden (2001). Complex causes of amphibian population declines. Nature, 410, 681-683.

Kleinosky, L.R., Yarnal, B., \& Fisher, A. (2007). Vulnerability of Hampton Roads, Virginia, to storm-surge flooding and sea-level rise. Natural Hazards, 40, 43-70.

Knowles, N., Dettinger, M.D., \& Cayan, D.R. (2006). Trends in snowfall versus rainfall

for the western United States, 1949-2004. Journal of Climate, 19, 4545-4559.

Kolivras, K.N., \& Comrie, A.C. (2003). Modeling valley fever (coccidioidomycosis) incidence on the basis of climate conditions. Int. J. Biometeorol, 47, 87-101.

Kossin, J. P., \& Camargo, S.J. (2009). Hurricane track variability and secular potential intensity trends. Climatic Change, 97, 329-337.

Kunkel, M.L., \& Pierce, J.L. (2010). Reconstructing snowmelt in Idaho's watershed using historic streamflow records. Climatic Change, 98, 155-176.

LaCommare, K.H., \& Eto, J.H. (2004). Understanding the cost of power interruptions to U.S. electricity consumers. LBNL-55718, Ernest Orlando Lawrence Berkeley National Laboratory, Berkeley, California, 70 pp. http://repositories.cdlib.org/cgi/viewcontent.cgi?article=2531\&context=lbnl. Accessed 02 September 2009.

Lemke, P., Ren, J., Alley, R., Allison, I., Carrasco, J., Flato, G., Fuji, Y., Kaser, G., Mote, P., Thomas, R.H., \& Zhang, T. (2007). Observations: changes in snow, ice and frozen ground. Climate Change 2007: The Physical 
Science Basis. Contribution of Working Group I to the Fourth Assessment Report of the Intergovernmental Panel on Climate Change, Solomon, S. Qin, D., Manning, M., Chen, Z., Marquis, M., Averyt, K.B., Tignor, M.\& Miller, H.L. Eds., Cambridge University Press, Cambridge and New York, 337-384.

Lemmen, D.S., \& Warren, F.J. Eds. (2004). Climate Change Impacts and Adaptation: A Canadian Perspective. Climate Change Impacts and Adaptation Directorate, Natural Resources Canada Ottawa, Ontario, 201 pp. http://environment.msu.edu/climatechange/canadaadaptation.pdf. Accessed 12 October 2009.

Lester, N.P., Dextrase, A.J., Kushneriuk, R.S., Rawson, M.R., \& Ryan, P.A. (2004). Light and temperature: Key factors affecting walleye abundance and production. Trans. Amer. Fish. Soc., 133, 588-605.

Lobell, D.B., \& Asner, P. (2003). Climate and management contributions to recent trends in U.S. agricultural yields. Science, 299, 1032.

Lobell, D.B., Cahill, K.N., \& Field, C.B. (2007). Historical effects of temperature and precipitation on California crop yields. Climatic Change, 81, 187-203.

Logan, J.A., Regniere, J.,\& Powell, J.A. (2003). Assessing the impacts of global warming on forest pest dynamics. Front. Ecol. Environ., 1, 130-137.

Lonergan, S., DiFrancesco, R., \& Woo, M. (1993). Climate change and transportation in northern Canada: An integrated impact assessment. Climatic Change, 24, 331-351.

Long, S.P., Ainsworth, E.A., Leakey, A.D.B., \& Morgan, P.B. (2005). Global food insecurity. Treatment of major food crops with elevated carbon dioxide or ozone under large-scale fully open-air conditions suggests recent models may have overestimated future yields. Phil. Trans. Royal Soc. Lond. B Biol. Sci., 360, 2011-2020.

Loukas, A., Vasiliades, L., \& Dalezios, N.R. (2002). Potential climate change impacts on flood producing mechanisms in southern British Columbia, Canada using the CGCMA1 simulation results. J. Hydrol., 259, 163-188.

McCabe, G.J., \& Bunnell, J.E. (2004). Precipitation and the occurrence of Lyme disease in the northeastern United States. Vector-Borne and Zoonotic Diseases, 4, 143-148.

McKenzie, D., Hessl, A.E., \& Peterson, D.L. (2001). Recent growth of conifer species of western North America: Assessing spatial patterns of radial growth trends. Can. J. For. Res., 31, 526-538.

Mearns, L.O., Carbone, G., Doherty, R.M., Tsvetsinskaya, E.A., McCarl, B.A., Adams, R.M., \& McDaniel, L. (2003). The uncertainty due to spatial scale of climate scenarios in integrated assessments: An example from U.S. agriculture. Integrated Assessment, 4, 225-235.

Meehl, G.A., \& Tebaldi, C. (2004). More intense, more frequent, and longer lasting heat waves in the 21st century. Science, 305, 994-997.

Meehl, G.A., Stocker, T.F., Collines, W.D., Friedlingstein, P., Gaye, A.T., Gregory, J.M., Kitoh, A., Knutti, R., Murphy, J.M., Noda, A., Raper, S.C.B., Watterson, I.G., Weaver, A.J., \& and Zhao, Z.C. (2007). Global climate projections. Climate Change 2007: The Physical Science Basis. Contribution of Working Group I to the Fourth Assessment Report of the Intergovernmental Panel on Climate Change, S. Solomon, D. Qin, M. Manning, Z. Chen, M. Marquis, K.B. Averyt, M. Tignor and H.L. Miller, Eds., Cambridge University Press, Cambridge and New York, 747-846.

Mendelsohn, R., Ed. (2001). Global Warming and the American Economy: A Regional Assessment of Climate Change Impacts. Edward Elgar, Northampton, Massachusetts, 209 pp.

Millett, B., Johnson, W.C., \& Guntenspergen, G. (2009). Climate trends of the North American prairie pothole region 1906-2000, Climatic Change, 93, 243-267.

Morgan, M.G., Pitelka, L.F.,\& Shevliakova, E. (2001). Elicitation of expert judgments of climate change impacts on forest ecosystems. Climatic Change, 49, 279-307.

Morrison, J., Quick, M.C., \& Foreman, M.G.G. (2002). Climate change in the Fraser River watershed: Flow and temperature projections. Journal of Hydrology (Amsterdam), 263, 230-244.

Morrison, W.N., \& Mendelsohn, R. (1999). The impact of global warming on U.S. energy expenditures. The Economic Impact of Climate Change on the United States Economy, R. Mendelsohn and J. Neumann, Eds., Cambridge University Press, New York, 209-236.

Mote, P., Hamlet, A.F., Clark, M.P., \& Lettenmaier, D.P. (2005). Declining mountain snowpack in western North America. Bull. Amer. Meteor. Soc., 86, 39-49. 
NAST (2001). Climate Change Impacts on the United States: The Potential Consequences of Climate Variability and Change, Foundation Report for the US Global Change Research Program. U.S. National Assessment Synthesis Team, Cambridge University Press, Cambridge, 620 pp. http://www.usgcrp.gov/usgcrp/Library/nationalassessment/foundation.htm. Accessed 02 October 2009.

O'Neal, K. (2002). Effects of Global Warming on Trout and Salmon in U.S. Streams. Defenders of Wildlife, Washington, District of Columbia, 46 pp. http://www.defenders.org/publications/fishreport.pdf. Accessed 02 October 2009.

Parson, E.A., Carter, L., Anderson, P., Wang, B., \& Weller, G. (2001). Potential consequences of climate variability and change for Alaska. Climate Change Impacts on the United States, National Assessment Synthesis Team, Ed., Cambridge University Press, Cambridge, 283-312.

Parson, E.A., Corell,, R.W. Barron, E.J., Burkett, V., Janetos, A., Joyce, L., Karl, T.R., MacCracken, M., Melillo, J., Morgan, M.G., Schimel, D.S., \& Wilbanks, T. (2003). Understanding climatic impacts, vulnerabilities and adaptation in the United States: Building a capacity for assessment. Climatic Change, 57, 9-42.

Patz, J.A., Campbell-Lendrum, D., Holloway, T., \& Foley, J.A. (2005). Impact of regional climate change on human health. Nature, 438, 310-317.

Pederson, G.T., Graumlich, L.J., Fagre, D.B., Kipfer, T., \& Muhlfeld, C.C. (2010). A century of climate and ecosystem change in Western Montana: what do temperature trends portend? Climatic Change, 98, 133-154.

Perez-Garcia, J., Joyce, L.A., McGuire, A.D., \& Xiao, X.M. (2002). Impacts of climate change on the global forest sector. Climatic Change, 54, 439-461.

Peterson, D.W., Peterson, D.L., \& Ettl, G.J. (2002). Growth responses of subalpine fir to climatic variability in the Pacific Northwest. Can. J. For. Res., 32, 1503-1517.

Pielke, Jr., R. A., Gratz, J., Landsea, C. W., Collins, D., Saunders, M. A., \& Musulin, R. (2008). Normalized Hurricane Damages in the United States: 1900-2005. Natural Hazards Review, 9, $29-42$.

Pounds, A.J. (2001). Climate and amphibian declines. Nature, 410, 639-640.

Reale, D., McAdam, A., Boutin, S., \& Berteaux, D. (2003). Genetic and plastic responses of a northern mammal to climate change. Proc. R. Soc. Lond. B, 591-596.

Reed, K.M., \& Czech, B. (2005). Causes of fish endangerment in the United States, or the structure of the American economy. Fisheries (Bethesda), 30, 36-38.

Rood, S.B., Samuelson, G.M., Weber, J.K., \& Wywrot, K.A. (2005). Twentieth-century decline in streamflows fromthe hydrographic apex of North America. J. Hydrol., 306, 215-233.

Rose, C.A. (2005). Economic growth as a threat to fish conservation in Canada. Fisheries, 30, 36-38.

Rosenberg, N.J., Brown, R.A., Izaurralde, R.C., \& Thomson, T.M. (2003). Integrated assessment of Hadley Centre (HadCM2) climate change projections on agricultural productivity and irrigation water supply in the conterminous United States: I. Climate change scenarios and impacts on irrigation water supply simulated with the HUMUS model. Agric. For. Meteorol., 117, 73-96.

Running, S.W. (2006). Is global warming causing more larger wildfires? Science, 313, 927-928.

Sailor, D.J., \& Pavlova, A.A. (2003). Air conditioning market saturation and long-term response of residential cooling energy demand to climate change. Energy, 28, 941-951.

Sala, O.A., Chapin III, F.S., Armesto, J.J., Berlow, E., Bloomfield, J., Dirzo, R., Huber-Sanwald, E., Huenneke, L.F., Jackson, R.B., Kinzig, A., Leemans, R., Lodge, D.M., Mooney, H.A., Oesterheld, M., Poff, N.L., Sykes, M.T., Walker, B.H., Walker, M., \& Wall, D.H. (2000). Global biodiversity scenarios for the year 2100. Science, 287, 1770-1774.

Scavia, D., Field, C., Boesch, D.F., Buddemeier, R.W., Burkett, V., Cayan, D.R., Fogarty, M., Harwell, M.A., Howarth, R.W., Mason, C., Reed, D.J., Royer, T.C., Sallenger, A.H., \& Titus, J.G. (2002). Climate change impacts on U.S. coastal and marine ecosystems. Estuaries, 25, 149-164.

Schindler, D. (2001). The cumulative effects of climate warming and other human stresses on Canadian freshwaters in the new millennium. Can. J. Fish Aquat. Sci., 58, 18-29.

Schoennagel, T., Veblen, T.T., \& Romme, W.H. (2004). The interaction of fire, fuels, and climate across Rocky Mountain Forests. BioScience, 54, 661-676. 
Schwartz, M., \& Reiter, B. (2000). Changes in North American spring. Int. J. Climatol., 20, 929-993.

Scott, D., \& Jones, B. (2005). Climate Change and Banff National Park: Implications for Tourism and Recreation - Executive Summary. Report prepared for the Town of Banff, Waterloo, Ontario, 29.

Scott, M.J., Dirks, J.A., \& Cort, K.A. (2005). The AdaptiveValue of Energy Efficiency Programs in a Warmer World: Building Energy Efficiency Offsets Effects of Climate Change. Proc. 2005 International Energy Program Evaluation Conference, Brooklyn, New York.

Select Bipartisan Committee (2006). A Failure of Initiative: Final Report of the Select Bipartisan Committee to Investigate the Preparation for and Response to Hurricane Katrina. Select Bipartisan Committee to Investigate the Preparation for and Response to Hurricane Katrina, U.S. House of Representatives (Select Committee), $109^{\text {th }}$ Congress, U.S. Government Printing Office, Washington, District of Columbia, 379 pp. Appendices. http://katrina.house.gov/full_katrina_report.htm. Accessed 02 October 2009.

Senate of Canada (2003). Climate Change: We are at Risk. Final Report, Standing Senate Committee on Agriculture and Forestry, Ottawa, Canada, 123 pp.

Small, C., \& Nichols, R.J. (2003). Aglobal analysis of human settlement. J. Coastal Res., 19, 584-599.

Smit, B., \& Skinner, M.W. (2002). Adaptation options in agriculture to climate change: Atypology. Mitigation Adapt. Strategies Global Change, 7, 85-114.

Smit, B., Burton, I., Klein, R.J.T., \& Wandel, J. (2000). An anatomy of adaptation to climate change and variability. Climatic Change, 45, 223-251.

Smith, S.J., Thomson, A.M., Rosenberg, N.J., Izaurralde, R.C., Brown, R.A., \& Wigley, T.M.L. (2005). Climate change impacts for the conterminous USA: An integrated assessment: Part 1. Scenarios and context. Climatic Change, 69, 7-25.

Sohngen, B., \& Sedjo, R. (2005). Impacts of climate change on forest product markets: Implications for North American producers. Forestry Chron., 81, 669-674.

Statistics Canada (2006). Agriculture Value Added Account: Agriculture Economic Statistics: June 2006. Statistics Canada, Ottawa, Ontario. http://www.statcan.ca/english/freepub/21-017-XIE/2006001/t026_en.htm? Accessed 02 October 2009.

Stott, P.A. (2003).Attribution of regional-scale temperature changes to anthropogenic and natural causes. Geophys. Res. Lett., 30.

Tarnoczi, T. J., \& Berkes, F. (2010). Sources of information for farmers' adaptation practices in Canada's Prairie agro-ecosystem. Climatic Change 98, 299-305.

The United States Global Change Program. (2009). http://www.globalchange.gov/ Accessed 25 November, 2010.

Thomas, C.D., Cameron, A., Green, R.E., Bakkenes, M., Beaumont, L.J., Collingham, Y.C., Erasmus, B.F.N., d. Siqueira, M.F., Grainger, A., Hannah, L., Hughes, L., Huntley, B., Jaarsveld, A.S. v., Midgley, G.F., Miles, L., Ortega-Huerta, M.A., Peterson, A.T., Phillips, O.L. \& Williams, S.E. (2004). Extinction risk from climate change. Nature, 427, 145-148.

Thomas, M.K., Charron, D.F., Waltner-Toews, D., Schuster, C., Maarouf, A.R., \& Holt, J.D. (2006). A role of high impact weather events in waterborne disease outbreaks in Canada, 1975-2001. Int. J. Environ. Health Res., $16,167-180$.

Thomson, A.M., Brown, R.A., Rosenberg, N.J., Izaurralde, R.C., \& Benson, V. (2005a). Climate change impacts for the conterminous USA: An integrated assessment. Part 3: Dryland production of grain and forage crops. Climatic Change, 69, 43-65.

Thomson, A.M., Brown, R.A., Rosenberg, N.J., Izaurralde, R.C., \& Srinivasan, R. (2005b). Climate change impacts for the conterminous USA: An integrated assessment. Part 4: Water resources. Climatic Change, 69, 67-88.

Thomson, A.M., Brown, R.A., Rosenberg, N.J., \& Izaurralde, R.C. (2005c). Climate change impacts for the conterminous USA: An integrated assessment. Part 5: Irrigated agriculture and national grain crop production. Climatic Change, 69, 89-105.

Travis, W. R. (2010). Going to extremes: propositions on the social response to severe climate change. Climatic Change 98, 1-19. 
Tsvetsinskaya, E.A., Mearns, L.O., Mavromatis, T., Gao, W., McDaniel, L., \& Downton, M.W. (2003). The effect of spatial scale of climatic change scenarios on simulated maize, winter wheat, and rice production in the southeastern United States. Climatic Change, 60, 37-72.

USAID (2009). Disaster assistance: OFDA Annual report for FY 2008: USAID.

Vincent, L., \& Mekis, E. (2006). Changes in daily and extreme temperature and precipitation indices for Canada over the twentieth century. Atmosphere-Ocean, 44, 177-193.

Volney, W.J.A., \& Fleming, R.A. (2000). Climate change and impacts of boreal forest insects. Agric. Ecosyst. Environ., 82, 283-294.

Wall, E., \& Smit, B. (2005). Climate change adaptation in light of sustainable agriculture.

J. Sustainable Agric., 27, 113-123.

West, J.J., Small, M.J., \& Dowlatabadi, H. (2001). Storms, investor decisions, and the economic impacts of sea level rise. Climatic Change, 48, 317-342.

Westerling, A.L., Hidalgo,H.G., Cayan, D.R., \& Swetnam, T.W. (2006). Warming and earlier spring increase western U.S. forest wildfire activity. Science, 313, 940-943.

Wheaton, E., Wittrock, V., Kulshretha, S., Koshida, G., Grant, C., Chipanshi, A., \& Bonsal, B. (2005). Lessons Learned from the Canadian Drought Years of 2001 and 2002: Synthesis Report. Saskatchewan Research Council Publication No. 11602- 46E03, Saskatoon, Saskatchewan, 38 pp. http://www.agr.gc.ca/pfra/drought/info/11602-46E03.pdf. Accessed 02 October 2009.

Williams, D.W., \& Liebhold, A.M. (2002). Climate change and the outbreak ranges of two North American bark beetles. Agric. For. Meteorol., 4, 87-99.

Wolfe, D.W., Schwartz, M.D., Lakso, A.N., Otsuki, Y., Pool, R.M., \& Shaulis, N.J. (2005). Climate change and shifts in spring phenology of three horticultural woody perennials in northeastern USA. International Journal of Biometeorol., 49, 303-309.

Woods, A., Coates, K.D., \& Hamann, A. (2005). Is an unprecedented dothistroma needle blight epidemic related to climate change? BioScience, 55, 761-769.

Woodward, F.I., \& Lomas, M.R. (2004). Vegetation dynamics - Simulating responses to climatic change. Biol. Rev., 79, 643-370.

Wu, S. Y., Najjar, R., \& Siewert, J. (2009). Potential impacts of sea-level rise on the Midand Upper-Atlantic Region of the United States. Climatic Change, 95, 121-138.

Zavaleta, E.S., \& Hulvey, K.B. (2004). Realistic species losses disproportionately reduce grassland resistance to biological invaders. Science, 306, 1175-1177.

Zhang, K.Q., Douglas, B.C., \& Leatherman, S.P. (2000). Twentieth-century storm activity along the U.S. east coast. Journal of Climate, 13, 1748-1761.

Zwiers, F., \& Zhang, X. (2003). Toward regional-scale climate change detection. Journal of Climate, 16, 793-797.

\section{Note}

Correspondence concerning this article should be addressed to Dr. Rachel J.C. Chen, Director of Center for Sustainable Business and Tourism, 311 Conference Center Building, the University of Tennessee, Knoxville, Tennessee 37996-4134; Phone: 1-865-974-0505; Email: rchen@utk.edu; Web: http://csbt.tennessee.edu/ 
Table 1. Changes of Temperature

\begin{tabular}{|c|c|c|c|c|}
\hline $\begin{array}{l}\text { Studied } \\
\text { Region }\end{array}$ & Variables / Method & Findings & $\begin{array}{l}\text { Conclusions } \\
\text { Suggestions }\end{array}$ & Reference \\
\hline the U.S. & $\begin{array}{l}\text { Climate } \text { Extremes Index } \\
\text { (CEI); U.S. Greenhouse } \\
\text { Climate Response Index } \\
\text { (GCRI); ARMA models }\end{array}$ & $\begin{array}{l}\text { Increase in temperature across the } \\
\text { U.S. is slightly smaller than the } \\
\text { global increase of temperature. } \\
\text { Both indices increased rather } \\
\text { abruptly during the } 1970 \mathrm{~s} \text {. }\end{array}$ & $\begin{array}{l}\text { Future studies may } \\
\text { consider adding new } \\
\text { indicators (e.g., winds, } \\
\text { hail, tornadoes, etc.) and } \\
\text { sulfate aerosols. }\end{array}$ & $\begin{array}{l}\text { Karl et al. } \\
(1996)\end{array}$ \\
\hline Canada & $\begin{array}{l}\text { 1900-98 (southern Canada); } \\
1950-98 \text { (the entire } \\
\text { country); daily and extreme } \\
\text { temperature related } \\
\text { variables }\end{array}$ & $\begin{array}{l}\text { Significant increases to the low } \\
\text { and high percentiles over the west, } \\
\text { and decreases over the east. }\end{array}$ & $\begin{array}{l}\text { Adding analyses to the } \\
\text { mean, extremes, and } \\
\text { variance of Canadian } \\
\text { daily temperature }\end{array}$ & $\begin{array}{l}\text { Bonsal et al. } \\
(2001)\end{array}$ \\
\hline the U.S. & $\begin{array}{l}\text { The Historical Climatology } \\
\text { Network Daily Dataset and } \\
\text { comprise daily maximum } \\
\text { and minimum temperatures }\end{array}$ & $\begin{array}{l}\text { A decrease in the number of frost } \\
\text { days, an earlier date of the } \\
\text { last-spring freeze, a later date of } \\
\text { the first-fall frost, and a } \\
\text { lengthening of the frost-free } \\
\text { season for the 1948-99 period. }\end{array}$ & $\begin{array}{l}\text { If stations } r \text { had } \\
\text { maintained a constant } \\
\text { observing } \\
\text { throughout the analysis } \\
\text { period that might affect } \\
\text { the results presented in } \\
\text { this study. }\end{array}$ & $\begin{array}{l}\text { Easterling } \\
(2002)\end{array}$ \\
\hline Canada & $\begin{array}{l}\text { 20th century trends and } \\
\text { variability in spring and } \\
\text { autumn } 0{ }^{\circ} \text { Cisotherm dates; } \\
\text { standard t-test }\end{array}$ & $\begin{array}{l}\text { Large-scale oscillations } \\
\text { representing atmospheric/oceanic } \\
\text { variations in the north Pacific and } \\
\text { north Atlantic were significantly } \\
\text { relate to isotherm dates. }\end{array}$ & $\begin{array}{lcr}\text { Future } & \text { studies } & \text { may } \\
\text { consider } & \text { adding } & \text { more } \\
\text { detailed } & \text { research } & \text { at } \\
\text { regional scales. } & \end{array}$ & $\begin{array}{l}\text { Bonsal \& } \\
\text { Prowse } \\
(2003)\end{array}$ \\
\hline $\begin{array}{l}\text { Six } \\
\text { Continents }\end{array}$ & $\begin{array}{l}\text { HADCM3, CRUTEM2(v) } \\
\text { dataset of near-surface air } \\
\text { temperatures over land; } \\
\text { December 1, } 1899 \text { to } \\
\text { November 30, } 1999\end{array}$ & $\begin{array}{l}\text { Significant anthropogenic } \\
\text { warming trends in the studied } \\
\text { continents. Greenhouse gases } \\
\text { were estimated to have caused } \\
\text { generally increasing warming. }\end{array}$ & $\begin{array}{l}\text { Future studies may } \\
\text { consider using different } \\
\text { climate models. }\end{array}$ & Stott (2003) \\
\hline $\begin{array}{l}\text { the North } \\
\text { American } \\
\text { region }\end{array}$ & $\begin{array}{lrr}\text { Indices } & \text { of } & \begin{array}{r}\text { large-scale } \\
\text { surface }\end{array} \\
\text { variation; } & & \text { comperature } \\
\text { observed } & & \text { temperature } \\
\text { changes } & & \end{array}$ & $\begin{array}{l}\text { There has been a significant } \\
\text { human influence on the observed } \\
\text { North American warming in the } \\
\text { second half of the 20th century. }\end{array}$ & $\begin{array}{l}\text { Adding other } \\
\text { anthropogenic forcing, } \\
\text { such as changes in land } \\
\text { cover or the role of } \\
\text { carbon black and other } \\
\text { non-sulfate aerosols at } \\
\text { regional scales }\end{array}$ & $\begin{array}{l}\text { Karoly et al. } \\
(2003)\end{array}$ \\
\hline $\begin{array}{l}\text { From the } \\
\text { globe to } \\
\text { Eurasia and } \\
\text { North } \\
\text { America }\end{array}$ & $\begin{array}{l}\text { monthly values of land } \\
\text { near-surface air temperature } \\
\text { anomalies and sea surface } \\
\text { temperature anomalies }\end{array}$ & $\begin{array}{l}\text { The effect of anthropogenic } \\
\text { forcing is detectable in the global } \\
\text { domain in the early and late } \\
\text { halves of the twentieth century is } \\
\text { in agreement with earlier } \\
\text { detection studies. }\end{array}$ & $\begin{array}{l}\text { Investigating other } \\
\text { models to quantify the } \\
\text { impact of signal } \\
\text { uncertainty \& extensions } \\
\text { to consider multiple } \\
\text { signals }\end{array}$ & $\begin{array}{l}\text { Zwiers et al. } \\
(2003)\end{array}$ \\
\hline the U.S. & $\begin{array}{l}\text { daily precipitation dataset at } \\
\text { the U.S. National Oceanic } \\
\text { and Atmospheric } \\
\text { Administration; daily } \\
\text { maximum and minimum } \\
\text { surface air temperatures } \\
(1950 \text { to } 2000)\end{array}$ & $\begin{array}{l}\text { Great Plains to the east coasts at a } \\
\text { rate of } 20 \text { Growing Degree Days } \\
\text { per } 10 \text { years; trend of decreasing } \\
\text { annual number of frost days at a } \\
\text { rate of } 3 \text { days per decade and a } \\
\text { trend of lengthening growing } \\
\text { season by } 4 \text { days per decade in the } \\
\text { western United States. }\end{array}$ & $\begin{array}{l}\text { Examining how the } \\
\text { climate change would } \\
\text { cause alternation of the } \\
\text { agro-environment for } \\
\text { growth and yield. }\end{array}$ & $\begin{array}{l}\text { Feng \& Hu } \\
(2004)\end{array}$ \\
\hline $\begin{array}{l}\text { Ontario, } \\
\text { Canada }\end{array}$ & $\begin{array}{l}\text { Literature reviews } \\
\text { (peer-reviewed journals, } \\
\text { books, government and } \\
\text { non-governmental } \\
\text { organization publications, } \\
\text { and websites); expert } \\
\text { opinions }\end{array}$ & $\begin{array}{l}\text { Climate change: have a net } \\
\text { positive effect on nature-based } \\
\text { tourism and outdoor recreation } \\
\text { activities; participation in snow } \\
\text { and ice-based activities will } \\
\text { decrease; negative effects on } \\
\text { traditional forest products } \\
\text { producers; changes in long-term } \\
\text { demand for Ontario's forests. }\end{array}$ & $\begin{array}{l}\text { Needs of more in-depth } \\
\text { and quantitative analysis; } \\
\text { More analysis of the } \\
\text { potential impacts to the } \\
\text { forest and tourism } \\
\text { industries }\end{array}$ & $\begin{array}{l}\text { Brosn \& } \\
\text { Hunt (2007) }\end{array}$ \\
\hline
\end{tabular}


Table 2. Rising Sea Levels

\begin{tabular}{|c|c|c|c|c|}
\hline Studied Region & Variables / Method & Findings & $\begin{array}{l}\text { Conclusions / } \\
\text { Suggestions }\end{array}$ & Reference \\
\hline $\begin{array}{l}\text { The U.S. East } \\
\text { Coast }\end{array}$ & $\begin{array}{l}\text { Storm surge data (hourly } \\
\text { tide gauge records); } \\
\text { measurement of storm } \\
\text { counts, duration and } \\
\text { intensity; Harmonic } \\
\text { analysis }\end{array}$ & $\begin{array}{l}\text { A considerable } \\
\text { inter-decadal variation } \\
\text { but no discernible } \\
\text { long-term trend in the } \\
\text { number and intensity } \\
\text { of moderate and severe } \\
\text { coastal storms during } \\
\text { this century. }\end{array}$ & $\begin{array}{l}\text { The intensive coastal } \\
\text { development becomes } \\
\text { more subject to flood } \\
\text { damage from coastal } \\
\text { storms. }\end{array}$ & $\begin{array}{l}\text { Zhanges et } \\
\text { al. (2000) }\end{array}$ \\
\hline the U.S. & $\begin{array}{l}\text { Literature reviews of } \\
\text { potential impacts on } \\
\text { shorelines, estuaries, } \\
\text { coastal wetlands, coral } \\
\text { reefs, and ocean margin } \\
\text { ecosystems }\end{array}$ & $\begin{array}{l}\text { Increasing rates of } \\
\text { sea-level rise and } \\
\text { intensity and } \\
\text { frequency of coastal } \\
\text { storms and hurricanes } \\
\text { over the next decades } \\
\text { will increase threats to } \\
\text { shorelines, wetlands, } \\
\text { and coastal } \\
\text { development. }\end{array}$ & $\begin{array}{l}\text { Future studies may } \\
\text { include other } \\
\text { ecosystem stresses such } \\
\text { as pollution, harvesting, } \\
\text { habitat destruction, } \\
\text { invasive species, land } \\
\text { and resource use, and } \\
\text { extreme natural events. }\end{array}$ & $\begin{array}{l}\text { Scavia et } \\
\text { al. (2002) }\end{array}$ \\
\hline the Global & $\begin{array}{l}\text { TOPEX/Poseidon satellite } \\
\text { altimeter data; historical } \\
\text { tide gauge data; }\end{array}$ & $\begin{array}{l}\text { A greater rate of sea } \\
\text { level rise on the } \\
\text { eastern North } \\
\text { American coast } \\
\text { compared with the } \\
\text { United Kingdom and } \\
\text { the Scandinavian } \\
\text { peninsula is found. }\end{array}$ & $\begin{array}{l}\text { Need more adequate } \\
\text { information on various } \\
\text { geophysical signatures } \\
\text { in the tide gauge data. }\end{array}$ & $\begin{array}{l}\text { Church et } \\
\text { al. (2004) }\end{array}$ \\
\hline $\begin{array}{l}\text { the North } \\
\text { Atlantic and } \\
\text { western North } \\
\text { Pacific }\end{array}$ & $\begin{array}{l}\text { the US Navy's Joint } \\
\text { Typhoon Warning Center } \\
\& \text { the National } \\
\text { Oceanographic \& } \\
\text { Atmospheric } \\
\text { Administration's National } \\
\text { Hurricane Center; defined } \\
\text { an index of the potential } \\
\text { destructiveness of } \\
\text { hurricanes }\end{array}$ & $\begin{array}{l}\text { Global warming may } \\
\text { result in an increase in } \\
\text { the circulation and an } \\
\text { increase in oceanic } \\
\text { enthalpy transport } \\
\text { from the tropics to } \\
\text { higher latitudes was } \\
\text { estimated. }\end{array}$ & $\begin{array}{l}\text { Only part of the } \\
\text { observed increase in } \\
\text { tropical cyclone power } \\
\text { dissipation is directly } \\
\text { due to increased SSTs; } \\
\text { the rest can only be } \\
\text { explained by changes } \\
\text { in other factors known } \\
\text { to influence hurricane } \\
\text { intensity, such as } \\
\text { vertical wind shear. }\end{array}$ & $\begin{array}{l}\text { Emanuel } \\
(2005)\end{array}$ \\
\hline Virginia, USA & $\begin{array}{l}\text { Used output from the } \\
\text { SLOSH (Sea, Lake, and } \\
\text { Overland Surges from } \\
\text { Hurricanes) model of the } \\
\text { National Hurricane Center; } \\
\text { A case of storm-surge } \\
\text { flooding }\end{array}$ & $\begin{array}{l}\text { The low-lying eastern } \\
\text { portion of the study } \\
\text { area is most at risk to } \\
\text { storm surges from } \\
\text { hurricanes of all } \\
\text { categories. }\end{array}$ & $\begin{array}{l}\text { Future studies may } \\
\text { include uncertainty in } \\
\text { rates of population } \\
\text { growth and in future } \\
\text { population distribution } \\
\text { patterns. }\end{array}$ & $\begin{array}{l}\text { Kleinosky } \\
\text { et al. } \\
\text { (2007) }\end{array}$ \\
\hline $\begin{array}{l}\text { New Jersey, } \\
\text { USA }\end{array}$ & $\begin{array}{l}\text { Digital elevation grids for } \\
\text { New Jersey's nine coastal } \\
\text { watersheds }\end{array}$ & $\begin{array}{l}\text { Coastal storms would } \\
\text { temporarily flood } \\
\text { low-lying areas up to } \\
20 \text { times more } \\
\text { frequently. }\end{array}$ & $\begin{array}{l}\text { Need to employ higher } \\
\text { resolution elevation } \\
\text { data and more accurate } \\
\text { mapping within models } \\
\text { with more detailed } \\
\text { analyses. }\end{array}$ & $\begin{array}{l}\text { Cooper et } \\
\text { al. (2008) }\end{array}$ \\
\hline $\begin{array}{l}\text { The Mid- and } \\
\text { Upper-Atlantic } \\
\text { Region, USA }\end{array}$ & $\begin{array}{l}\text { The output of five global } \\
\text { climate models (GCMs); } \\
\text { two greenhouse gas } \\
\text { scenarios; tide gauge } \\
\text { observations; projection of } \\
\text { sea-level increases }\end{array}$ & $\begin{array}{l}\text { The projections of } \\
\text { scenario-mean } \\
\text { sea-level rise by } 2100 \\
\text { in the region vary from } \\
400 \text { to } 700 \mathrm{~mm} \text {. }\end{array}$ & $\begin{array}{l}\text { Future studies may } \\
\text { include elevated storm } \\
\text { surges, loss of coastal } \\
\text { wetland, and salt water } \\
\text { intrusion. }\end{array}$ & $\begin{array}{l}\text { Wu et al. } \\
\text { (2009) }\end{array}$ \\
\hline
\end{tabular}


Table 3. Extreme Weather Events

\begin{tabular}{|c|c|c|c|c|}
\hline $\begin{array}{l}\text { Studied } \\
\text { Region }\end{array}$ & Variables / Method & Findings & Suggestion & Reference \\
\hline $\begin{array}{l}\text { Global and } \\
\text { the U.S. }\end{array}$ & $\begin{array}{l}\text { Literature reviews: past } \\
\text { changes; climate } \\
\text { extremes through } \\
\text { climate modeling; the } \\
\text { potential impacts of } \\
\text { climate extremes on } \\
\text { society }\end{array}$ & $\begin{array}{l}\text { Model output showed that } \\
\text { there are increases in } \\
\text { extreme high temperatures, } \\
\text { decreases in extreme low } \\
\text { temperatures, and increases } \\
\text { in intense precipitation } \\
\text { events for future climate. }\end{array}$ & $\begin{array}{l}\text { Need consensus on the } \\
\text { definition of extreme } \\
\text { events; needs of suitable } \\
\text { homogeneous data for } \\
\text { many parts of the world }\end{array}$ & $\begin{array}{l}\text { Easterling } \\
\text { et al. }(2000)\end{array}$ \\
\hline The U.S. & Literature reviews & $\begin{array}{l}\text { Despite the numerical } \\
\text { simulation results, } \\
\text { empiricists have been unable } \\
\text { to identify significant } \\
\text { increases in overall severe } \\
\text { storm activity as measured in } \\
\text { the magnitude and/or } \\
\text { frequency. }\end{array}$ & $\begin{array}{l}\text { Damage from severe } \\
\text { weather has increased } \\
\text { over this period, but this } \\
\text { upward trend disappears } \\
\text { when inflation, } \\
\text { population growth, } \\
\text { population } \\
\text { redistribution, and } \\
\text { wealth are taken into } \\
\text { account. }\end{array}$ & $\begin{array}{l}\text { Balling \& } \\
\text { Cerveny } \\
\text { (2003) }\end{array}$ \\
\hline $\begin{array}{l}\text { California } \\
\text { Coast, } \\
\text { USA }\end{array}$ & $\begin{array}{l}\text { Hourly tide gauge data } \\
\text { from the National } \\
\text { Oceanic and } \\
\text { Atmospheric } \\
\text { Administration } \\
\text { National Ocean Service } \\
\text { Center for Operational } \\
\text { Oceanographic } \\
\text { Products and Services }\end{array}$ & $\begin{array}{l}\text { Atmospheric sea level } \\
\text { pressure anomalies take the } \\
\text { form of a distinct, } \\
\text { large-scale atmospheric } \\
\text { circulation pattern, with } \\
\text { intense storminess associated } \\
\text { with a broad, southeasterly } \\
\text { displaced, deep Aleutian low } \\
\text { that directs storm tracks } \\
\text { toward the California coast. }\end{array}$ & $\begin{array}{l}\text { Need to examine if the } \\
\text { observed historical } \\
\text { pattern of inter-decadal, } \\
\text { quasi-cyclic winter } \\
\text { storminess holds true. }\end{array}$ & $\begin{array}{l}\text { Bromirski } \\
\text { et al. (2003) }\end{array}$ \\
\hline The U.S. & $\begin{array}{l}\text { Literature reviews; } \\
\text { adjusted raw loss data } \\
\text { for seven major weather } \\
\text { extremes during the } \\
1950-1997 \text { period. }\end{array}$ & $\begin{array}{l}\text { Annual national losses } \\
\text { during } 1950-1997 \text { from the } \\
\text { three major extremes } \\
\text { (hurricanes, floods, and } \\
\text { storms), plus hail, tornadoes, } \\
\text { winter storms, and wind } \\
\text { storms, with an average } \\
\text { annual loss of } \$ 10.3 \text { billion. }\end{array}$ & $\begin{array}{l}\text { The U.S. needs a } \\
\text { continuing program to } \\
\text { adequately measure } \\
\text { losses from weather } \\
\text { extremes. }\end{array}$ & $\begin{array}{l}\text { Changnon } \\
\text { (2003) }\end{array}$ \\
\hline The U.S. & $\begin{array}{l}\text { Literature reviews that } \\
\text { included impacts of } \\
\text { climate extremes, } \\
\text { impacts of extremes } \\
\text { and the nation's } \\
\text { economy, potential } \\
\text { future economic } \\
\text { impacts from a changed } \\
\text { climate }\end{array}$ & $\begin{array}{l}\text { The losses and gains defined } \\
\text { for } 1950-2000 \text {, were used to } \\
\text { develop a list of average } \\
\text { annual national losses and } \\
\text { gains for various sectors of } \\
\text { the economy - the changes } \\
\text { are extremely small. }\end{array}$ & $\begin{array}{l}\text { Need to assure the } \\
\text { reliability of the use of } \\
\text { economic models for } \\
\text { future economic } \\
\text { impacts. }\end{array}$ & $\begin{array}{l}\text { Changnon } \\
(2005)\end{array}$ \\
\hline $\begin{array}{l}\text { Florida, } \\
\text { USA }\end{array}$ & $\begin{array}{l}\text { the effects of tropical } \\
\text { storms and hurricanes } \\
\text { on the natural } \\
\text { resources; various } \\
\text { long-term monitoring } \\
\text { programs in the } \\
\text { Apalachicola Bay area }\end{array}$ & $\begin{array}{l}\text { Long-term impacts include } \\
\text { changes to the structure of } \\
\text { the beach, dunes, and } \\
\text { bayside areas on a barrier } \\
\text { island and loss of or changes } \\
\text { in submerged aquatic } \\
\text { vegetation distribution. }\end{array}$ & $\begin{array}{l}\text { Need to have long-term } \\
\text { monitoring, coupled } \\
\text { with short-term studies } \\
\text { and proper management } \\
\text { of natural resources. }\end{array}$ & $\begin{array}{l}\text { Edmiston et } \\
\text { al. (2008) }\end{array}$ \\
\hline
\end{tabular}


Table 4. Diseases vs. Extreme Weather

\begin{tabular}{|c|c|c|c|c|}
\hline $\begin{array}{l}\text { Studied } \\
\text { Region }\end{array}$ & Variables / Method & Findings & Suggestion & Reference \\
\hline $\begin{array}{l}\text { Arizona, } \\
\text { USA }\end{array}$ & $\begin{array}{l}\text { Monthly valley fever } \\
\text { incidence data for } \\
\text { Pima County } \\
(1948-1998)\end{array}$ & $\begin{array}{l}\text { There were relationships } \\
\text { between valley fever } \\
\text { incidence and climate } \\
\text { conditions and variability. } \\
\text { Soaking rains may provide } \\
\text { the moisture needed for } \\
\text { the fungus to grow within } \\
\text { the soil. }\end{array}$ & $\begin{array}{l}\text { Needs of better time series } \\
\text { data: future modeling could } \\
\text { be combined with spatial } \\
\text { variables including soil } \\
\text { type, disturbance regime, } \\
\text { and proximity to a riparian } \\
\text { zone. }\end{array}$ & $\begin{array}{l}\text { Kolivras \& } \\
\text { Comrie } \\
(2003)\end{array}$ \\
\hline $\begin{array}{l}\text { Northeastern } \\
\text { USA }\end{array}$ & $\begin{array}{l}\text { Human case reports } \\
\text { for the Northeast and } \\
\text { Mid-Atlantic regions } \\
\text { of the United States } \\
(1992-2002)\end{array}$ & $\begin{array}{l}\text { When late spring/early } \\
\text { summer precipitation was } \\
\text { greater than average, the } \\
\text { occurrence of Lyme } \\
\text { disease was above } \\
\text { average. }\end{array}$ & $\begin{array}{l}\text { Future studies need to fully } \\
\text { identify and quantify links } \\
\text { between climate and the } \\
\text { occurrence of Lyme } \\
\text { disease. }\end{array}$ & $\begin{array}{l}\text { McCabe \& } \\
\text { Bunnell } \\
(2004)\end{array}$ \\
\hline the Global & literature reviews & $\begin{array}{l}\text { The effect of heat waves is } \\
\text { exacerbated in large cities } \\
\text { owing to the urban heat } \\
\text { island effect. }\end{array}$ & $\begin{array}{l}\text { Future projections of } \\
\text { land-use change may be } \\
\text { considered. }\end{array}$ & $\begin{array}{l}\text { Patz et al. } \\
(2005)\end{array}$ \\
\hline Canada & $\begin{array}{l}\text { extreme rainfall and } \\
\text { spring snowmelt in } \\
\text { association with } 92 \\
\text { Canadian } \\
\text { waterborne disease } \\
\text { outbreaks }\end{array}$ & $\begin{array}{l}\text { Warmer temperatures and } \\
\text { extreme rainfall are } \\
\text { contributing factors to } \\
\text { waterborne disease } \\
\text { outbreaks. }\end{array}$ & $\begin{array}{l}\text { Future studies may include } \\
\text { variables of the } \\
\text { microbiological causes, } \\
\text { source water characteristics } \\
\text { and characteristics of water } \\
\text { treatment. }\end{array}$ & $\begin{array}{l}\text { Thomas et } \\
\text { al. (2006) }\end{array}$ \\
\hline The Global & $\begin{array}{l}\text { Numerous methods } \\
\text { have been identified } \\
\text { in the literature for } \\
\text { calculating the } \\
\text { expected mortality, } \\
\text { dependent upon the } \\
\text { chosen baseline. }\end{array}$ & $\begin{array}{l}\text { The elderly and those with } \\
\text { existing diseases such as } \\
\text { ischemic heart disease, } \\
\text { respiratory disease, } \\
\text { cardiovascular disease, } \\
\text { and chronic obstructive } \\
\text { pulmonary disease are } \\
\text { most susceptible to } \\
\text { extreme temperatures. }\end{array}$ & $\begin{array}{l}\text { Observations are used not } \\
\text { only in the development of } \\
\text { the temperature-mortality } \\
\text { relationships but also to } \\
\text { constrain future climate } \\
\text { predictions. }\end{array}$ & $\begin{array}{l}\text { Gosling et } \\
\text { al. (2009) }\end{array}$ \\
\hline
\end{tabular}


Table 5. Water Resources vs. Climate Change

\begin{tabular}{|c|c|c|c|c|}
\hline $\begin{array}{l}\text { Studied } \\
\text { Region }\end{array}$ & Variables / Method & Findings & Suggestion & Reference \\
\hline $\begin{array}{l}\text { Texas, } \\
\text { USA }\end{array}$ & $\begin{array}{l}\text { combined various } \\
\text { pumping scenarios } \\
\text { with the } 2 \text { X CO2 } \\
\text { climate scenario; } \\
\text { assessment of the } \\
\text { sensitivity of water } \\
\text { resources impacts }\end{array}$ & $\begin{array}{l}\text { Climatic conditions are } \\
\text { likely to exacerbate negative } \\
\text { impacts and water shortages } \\
\text { in the Edwards BFZ aquifer } \\
\text { unless ground water } \\
\text { withdrawal is carefully } \\
\text { adjusted. }\end{array}$ & $\begin{array}{l}\text { Under drought } \\
\text { conditions there is no } \\
\text { pumping strategy that } \\
\text { could prevent } \\
\text { discharge shortages at } \\
\text { San Marcos and Comal } \\
\text { springs. }\end{array}$ & $\begin{array}{l}\text { Loaiciga et al. } \\
(2000)\end{array}$ \\
\hline $\begin{array}{l}\text { Vermont, } \\
\text { USA }\end{array}$ & $\begin{array}{l}\text { Data were from: } \\
\text { Northeast Regional } \\
\text { Climate Center, } \\
\text { National Climatic } \\
\text { Data Center, } \\
\text { Northeast River } \\
\text { Forecast Center, and } \\
\text { National Weather } \\
\text { Service }\end{array}$ & $\begin{array}{l}\text { From a number of } \\
\text { precipitation statistics and } \\
\text { drought indices, fine spatial } \\
\text { scales (county or better) } \\
\text { were found to best capture } \\
\text { the character of drought } \\
\text { impacts. }\end{array}$ & $\begin{array}{l}\text { Drought planning } \\
\text { efforts should be } \\
\text { focused at the county } \\
\text { level or smaller to } \\
\text { eliminate potential } \\
\text { biases. }\end{array}$ & $\begin{array}{l}\text { Dupigny-Giroux } \\
\text { (2001) }\end{array}$ \\
\hline $\begin{array}{l}\text { British } \\
\text { Columbia, } \\
\text { Canada }\end{array}$ & $\begin{array}{l}\text { the UBC watershed } \\
\text { model; two British } \\
\text { Columbia } \\
\text { watersheds. Data } \\
\text { were from three } \\
\text { meteorological } \\
\text { stations }\end{array}$ & $\begin{array}{l}\text { The flood magnitude and } \\
\text { frequency of occurrence in } \\
\text { the Upper Campbell } \\
\text { watershed would increase. } \\
\text { The number and the } \\
\text { magnitude of the flood flows } \\
\text { would decrease under the } \\
\text { future climatic conditions. }\end{array}$ & $\begin{array}{l}\text { Future studies may } \\
\text { consider integrating the } \\
\text { outcomes of this study } \\
\text { with suitable future } \\
\text { forest management } \\
\text { practices. }\end{array}$ & $\begin{array}{l}\text { Loukas et al. } \\
(2002)\end{array}$ \\
\hline $\begin{array}{l}\text { The Raser } \\
\text { River, } \\
\text { Canada }\end{array}$ & $\begin{array}{l}\text { the Canadian Centre } \\
\text { for Climate } \\
\text { Modeling; Analysis } \\
\text { model CGCM1 }\end{array}$ & $\begin{array}{l}\text { For the period } 2070-2099, \\
\text { the flow model predicted a } \\
\text { modest } 5 \% \text { average flow } \\
\text { increase but a decrease in } \\
\text { the average peak flow of } \\
\text { about } 18 \% \text {. }\end{array}$ & $\begin{array}{l}\text { Future studies may run } \\
\text { the temperature model } \\
\text { with predictions from } \\
\text { more than just the one } \\
\text { GCM. }\end{array}$ & $\begin{array}{l}\text { Morrison et al. } \\
(2002)\end{array}$ \\
\hline $\begin{array}{l}\text { California, } \\
\text { USA }\end{array}$ & $\begin{array}{l}\text { the Sacramento Soil } \\
\text { Moisture Accounting } \\
\text { Model and Anderson } \\
\text { Snow Model }\end{array}$ & $\begin{array}{l}\text { The hydrologic response } \\
\text { varies for each scenario. The } \\
\text { late winter snow } \\
\text { accumulation decreases by } \\
50 \text { percent toward the end of } \\
\text { this century. }\end{array}$ & $\begin{array}{l}\text { GCMs should continue } \\
\text { to improve in accuracy } \\
\text { with further studies to } \\
\text { evaluate their results } \\
\text { and reduce model bias. }\end{array}$ & $\begin{array}{l}\text { Miller et al. } \\
(2003)\end{array}$ \\
\hline $\begin{array}{l}\text { British } \\
\text { Columbia, } \\
\text { Canada }\end{array}$ & $\begin{array}{l}\text { Modeled the } \\
\text { sensitivity of an } \\
\text { aquifer to changes in } \\
\text { recharge and river } \\
\text { stage with projected } \\
\text { climate-change } \\
\text { scenarios }\end{array}$ & $\begin{array}{l}\text { Models under steady-state } \\
\text { conditions, have a much } \\
\text { smaller impact on the } \\
\text { groundwater system than } \\
\text { changes in river-stage } \\
\text { elevation }\end{array}$ & $\begin{array}{l}\text { Future studies need to } \\
\text { re-evaluate this model } \\
\text { to address issues } \\
\text { related to sustainability } \\
\text { of groundwater } \\
\text { resources. }\end{array}$ & $\begin{array}{l}\text { Allen et al. } \\
(2004)\end{array}$ \\
\hline the U.S. & $\begin{array}{l}6000 \text { stations with } \\
\text { daily records of } \\
\text { precipitation, } \\
\text { minimum and } \\
\text { maximum } \\
\text { temperatures, } \\
\text { snowfall, snow depth, } \\
\text { pan evaporation; } \\
\text { linear trend estimates; } \\
\text { least squares } \\
\text { regression }\end{array}$ & $\begin{array}{l}\text { Soil wetness has increased } \\
\text { over the northern and } \\
\text { eastern regions, but in the } \\
\text { southwestern quadrant of the } \\
\text { country soil dryness has } \\
\text { increased, making the region } \\
\text { more susceptible to forest } \\
\text { fires. }\end{array}$ & $\begin{array}{l}\text { Parameterization of } \\
\text { these changes by } \\
\text { assigning them to the } \\
\text { macro-circulation } \\
\text { variables was beyond } \\
\text { the scope of this study. }\end{array}$ & $\begin{array}{l}\text { Groisman et al. } \\
(2005)\end{array}$ \\
\hline
\end{tabular}




\begin{tabular}{|c|c|c|c|c|}
\hline $\begin{array}{l}\text { the } \\
\text { western } \\
\text { North } \\
\text { America }\end{array}$ & $\begin{array}{l}\text { Snow course data, } \\
\text { climate data; the } \\
\text { Variable Infiltration } \\
\text { Capacity hydrologic } \\
\text { model; simple } \\
\text { multiple linear } \\
\text { regressions }\end{array}$ & $\begin{array}{l}\text { Cold, high elevation areas } \\
\text { and those with very large } \\
\text { increases in precipitation } \\
\text { (the Southwest) showed } \\
\text { positive trends in SWE from } \\
1950 \text { to } 1997 .\end{array}$ & $\begin{array}{l}\text { A small fraction of the } \\
\text { variance of } \\
\text { precipitation is } \\
\text { explained by any of the } \\
\text { Pacific climate indices, } \\
\text { and the widespread } \\
\text { monotonic increases in } \\
\text { temperature exceed } \\
\text { what can be explained } \\
\text { by Pacific climate } \\
\text { variability. }\end{array}$ & $\begin{array}{l}\text { Mote et al. } \\
(2005)\end{array}$ \\
\hline $\begin{array}{l}\text { the North } \\
\text { American } \\
\text { hydrograp } \\
\text { hic apex, } \\
\text { the } \\
\text { Canada-U } \\
\text { nited } \\
\text { States }\end{array}$ & $\begin{array}{l}\text { Mean annual } \\
\text { discharge from } 31 \\
\text { river reaches; } \\
\text { hydrologic records } \\
\text { (in the } 1910 \text { s and } \\
\text { extending to about } \\
\text { 2002); Spearman r } \\
\text { and Kendall t } \\
\text { non-parametric } \\
\text { correlations; linear } \\
\text { regressions }\end{array}$ & $\begin{array}{l}\text { The historic decline of total } \\
\text { annual flow of the rivers } \\
\text { draining relatively pristine } \\
\text { Rocky Mountain watersheds } \\
\text { near the hydrographic apex } \\
\text { of North America. }\end{array}$ & $\begin{array}{l}\text { Future studies need to } \\
\text { consider ecological } \\
\text { related variables. }\end{array}$ & $\begin{array}{l}\text { Rood et al } \\
(2005)\end{array}$ \\
\hline $\begin{array}{l}\text { the } \\
\text { Western } \\
\text { United } \\
\text { States }\end{array}$ & $\begin{array}{l}\text { A regional trend } \\
\text { toward smaller ratios } \\
\text { of winter-total } \\
\text { snowfall water } \\
\text { equivalent (SFE) to } \\
\text { winter-total } \\
\text { precipitation }(P) \\
(1949-2004)\end{array}$ & $\begin{array}{l}\text { Extending the analysis back } \\
\text { to } 1920 \text { shows that the } \\
\text { trends presented here may } \\
\text { be partially attributable to } \\
\text { inter-decadal climate } \\
\text { variability associated with } \\
\text { the Pacific decadal } \\
\text { oscillation. }\end{array}$ & $\begin{array}{l}\text { Better understanding of } \\
\text { how flood risks will } \\
\text { change. }\end{array}$ & $\begin{array}{l}\text { Knowles et al. } \\
(2006)\end{array}$ \\
\hline $\begin{array}{l}\text { British } \\
\text { Columbia, } \\
\text { Canada }\end{array}$ & $\begin{array}{l}\text { Three global climate } \\
\text { models (GCMs); high } \\
\text { (A2) and low (B2) } \\
\text { emission scenarios }\end{array}$ & $\begin{array}{l}\text { All scenarios consistently } \\
\text { predicted an early onset of } \\
\text { the spring snowmelt, a } \\
\text { tendency towards a more } \\
\text { rainfall dominated } \\
\text { hydrograph and considerable } \\
\text { reductions in the annual and } \\
\text { spring flow volumes in the } \\
2050 \text { s and 2080s. }\end{array}$ & $\begin{array}{l}\text { The scenarios raise } \\
\text { questions regarding the } \\
\text { availability of future } \\
\text { water resources. }\end{array}$ & $\begin{array}{l}\text { Merritt et al. } \\
(2006)\end{array}$ \\
\hline The U.S. & $\begin{array}{l}\text { Thornthwaite's } \\
\text { moisture index; } 344 \\
\text { climate divisions } \\
\text { across the United } \\
\text { States (1895-2006); } \\
\text { Linear trends }\end{array}$ & $\begin{array}{l}\text { Much of the United States is } \\
\text { becoming wetter, despite the } \\
\text { pattern of increasing } \\
\text { temperatures. }\end{array}$ & $\begin{array}{l}\text { Future studies may } \\
\text { consider whether there } \\
\text { has been any change in } \\
\text { the variability of the } \\
\text { moisture index. }\end{array}$ & $\begin{array}{l}\text { Grundstein, } \\
(2009)\end{array}$ \\
\hline Canada & $\begin{array}{l}\text { Literature reviews: } \\
\text { recent progress in } \\
\text { research in Canada } \\
\text { over the past four } \\
\text { years }(2003-2007)\end{array}$ & $\begin{array}{l}\text { The coupling of hydrologic } \\
\text { change with biogeochemical } \\
\text { processes is essential to } \\
\text { understand the impacts of a } \\
\text { changing climate on water } \\
\text { quality. }\end{array}$ & $\begin{array}{l}\text { Progress in the area } \\
\text { will accelerate with } \\
\text { improved } \\
\text { communication among } \\
\text { the water disciplines. }\end{array}$ & $\begin{array}{l}\text { Branfireun \& } \\
\text { Macrae, (2009) }\end{array}$ \\
\hline
\end{tabular}

